\title{
Impact of Gas Composition, Temperature and Pre-Treatments on Mint Leaves Quality under Modified Atmosphere Packaging
}

\author{
M.M. Pragalyaashree ${ }^{1 *}$, V. Thirupathi ${ }^{2}$ and Z. John Kennedy ${ }^{2}$ \\ ${ }^{1}$ Department of BioSciences and Technology, Karunya University, Coimbatore - 641114, India \\ ${ }^{2}$ Department of Food and Agricultural Process Engineering, Agricultural Engineering College \\ and Research Institute, Tamil Nadu Agricultural University, Coimbatore-3, Tamil Nadu, India \\ *Corresponding author
}

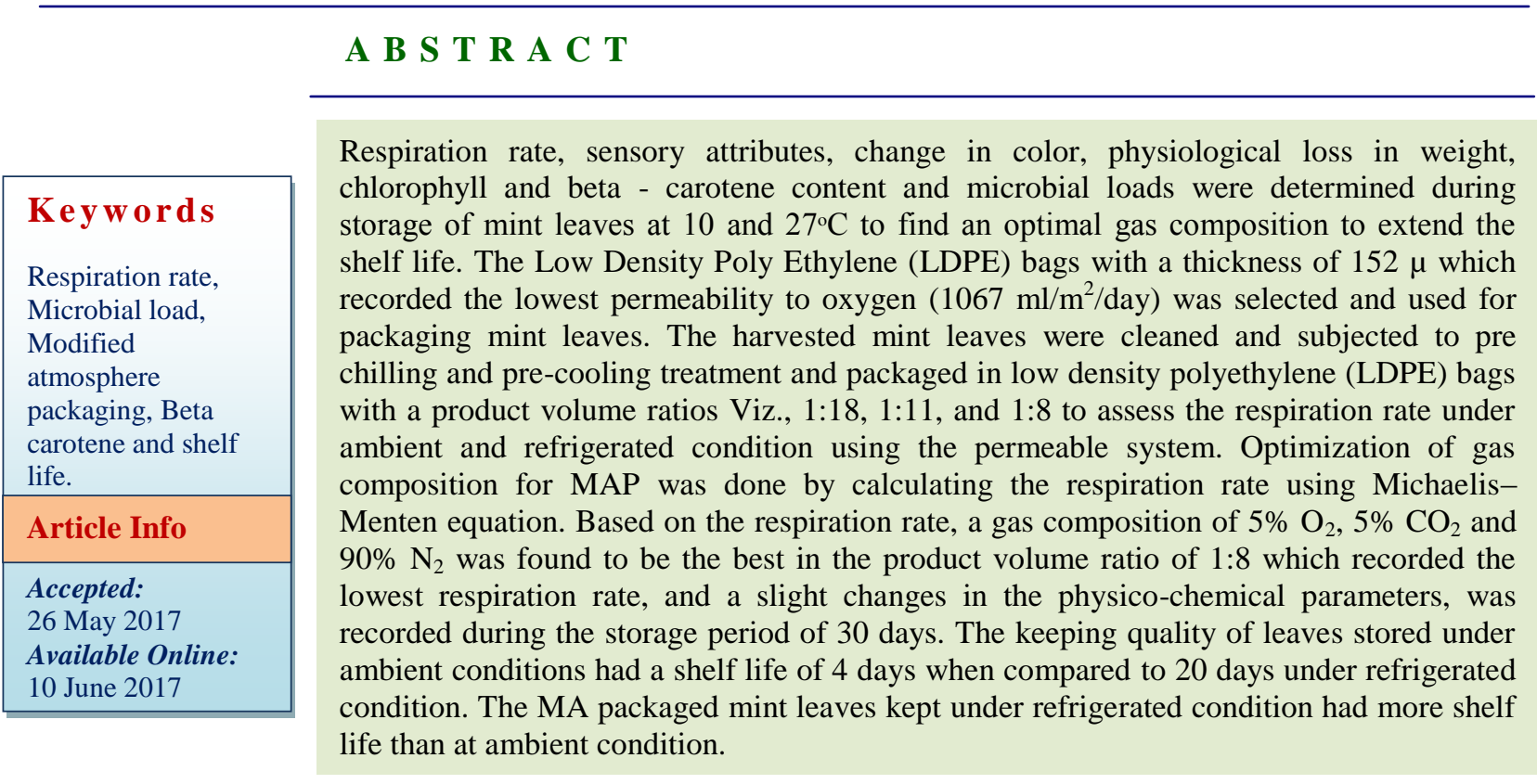

\section{Introduction}

Green leafy vegetables supply adequate amounts of vitamins, minerals, less fat, high dietary fibre, rich folic acid, vitamin C, potassium, magnesium and calcium. They are rich in beta-carotene, iron and good sources of zinc, manganese cobalt, copper and many other minerals. They are highly perishable due to loss of water, high senescence and loss of chlorophyll which leads to accumulation of $\mathrm{CO}_{2}$ followed by yellowing and decay when stored at high temperature products [Paull, (1992); Yamauchi and Watada (1991) and
Aharoni et al., (1989)]. Leafy vegetables will respire even after they are cut and packaged. The physiological requirements must be met or they will rapidly deteriorate. During respiration, green leafy vegetables are constantly consuming oxygen and producing carbon dioxide, heat and water. These rates can be slower down by holding the fruit at low temperature. Leafy vegetables will modify the package environment and their physiology will be modified. The changes in gas composition of the package environment 
are referred to as MAP and this technology is central to maintaining the quality of shelf life of fresh produce. The atmosphere that exists inside a MAP is a function of the film and the product. Hence it is essential to know the respiratory requirements of the products and the permeability properties of the film. The appropriate atmosphere, and proper temperature, to be maintained for a give commodity to realise the optimum quality and postharvest life.

Permeability is typically slow compared to the normal movements of the gases in air, so that the films acts as a partial barrier to gas movement. When the permeation of gas is slow, close to zero, the film is called as barrier film. Flexible films vary in their rates of gas transmission, commonly known as oxygen transmission rate (OTR) or carbon dioxide transmission rate $\mathrm{CO}_{2}$ TR). Films with intermediate gas diffusion rates are more applicable for packaging respiring commodities.

Quality characteristics of culinary herbs include fresh appearance, colour, aroma and flavour and lack of defects like decay and yellowing (Cantwell and Reid, 1993). Fresh mint leaves have very short shelf life under the ambient conditions. The production of high quality mint leaves possess unique challenges to food processors due to high water activity, respiration, senescence, and loss of chlorophyll, undesirable physiological changes, contamination and growth of micro flora. Hence there is a need to mitigate the above damages by proper handling and post harvest processing techniques.

The respiration of fresh herbs can be reduced by many preservation techniques like low temperature, canning, dehydration, freezedrying, controlled atmosphere, hypobaric and modified atmosphere. Dehydration also controls the activity of microorganisms by the removal of water under controlled conditions of temperature, pressure and relative humidity (Sandhya, 2010).

Rajesh (2001) stated that horticultural commodities are different from other food products as they are living organisms. The high respiration rate and other metabolic process associated with ripening of these products continue throughout the marketing cycle. Modified atmosphere packaging technique could be used effectively to inhibit both biological and chemical degradation (Jayas and Jeyamkondan, 2002).

Modified atmosphere packaging can be defined as 'the enclosure of food products in a film in which the gaseous environment has been changed or modified to slow respiration rates, reduce microbiological growth, and retarded enzymatic spoilage with the intent of extending shelf life'. MAP is becoming an increasingly popular methods of shelf life extension of food products when an extended shelf life at refrigerated temperature is required.

MAP utilizes polymeric films with selective permeability for $\mathrm{O}_{2}, \mathrm{CO}_{2}$ and water vapour to create a modified atmosphere around the packaged product due to respiration of the product and the selective permeability of the packaging material (Guevara et. al., 2003). The atmosphere within the packaging changes over storage time due to factors such as product respiration and biochemical changes, as well as the slow diffusion of the gases through the packaging film. There are many factors to take into account with this technique, such film permeability $\left(\mathrm{O}_{2}, \mathrm{CO}_{2}\right.$, water vapour) or temperature, that make it essential to fix the optimal conditions for each vegetable product (Fonseca, Oliveira, and Brecht, 2002). Application of reduced levels of $\mathrm{O}_{2}$ and increased levels of $\mathrm{CO}_{2}$ in the atmosphere surrounding fresh produce has 
several positive effects on respiration rate, ethylene production and sensitivity, texture losses, improves chlorophyll and other pigment retention, delays ripening and senescence reduces the rate of microbial growth and spoilage (Aguilera and Olivera, 2009).

This study has been carried out to evaluate the effect of MAP storage and temperature conditions on shelf life of mint leaves. The objective was the study of two MAP conditions: the first one combined with refrigeration at $7 \pm 1^{\circ} \mathrm{C}$, is recommended for commercialisation and the second was carried out in order to compare these results with normal atmosphere conditions.

The evaluation was done by measuring the variation of physiological, physical, chemical and microbiological characteristics over the storage periods.

\section{Materials and Methods}

The mint leaves, which has a commercial utility as culinary herbs were taken for the study. After harvest, the mint leaves were trimmed cleaned and shade dried to remove the surface moisture (Fig. 1).

\section{Pre treatments}

The cleaned mint leaves are bundled @ 50,75 and $100 \mathrm{~g}$ and are subjected to pretreatments like pre-chilling and pre-cooling to reduce the field heat.

\section{Pre-chilling}

Pre chilling treatment was given by soaking the bundles in chilled water for 10 minutes so that translocation of chilled water to the aerial parts of the leaves may occur without causing chilling injury, and to reduce the field heat. The chilling temperature and duration was optimized by conducting respiration studies. The temperature was optimized as $5^{\circ} \mathrm{C}$ and the duration was 10 minutes for best results.

\section{Pre-cooling}

Pre cooling involves the removal of field heat from freshly harvested produce in order to slow down metabolism and reduce deterioration prior to transport or storage (Janick, 1986). Baird and Gafney (1976) pointed out that pre cooling is likely the most important of all the operations used in the maintenance of desirable, fresh and salable produce. To study and compare the effect cold water treatment, pre cooling was done at $7 \pm 2^{\circ} \mathrm{C}$ for 10 minutes before the leaf bundles are subjected to modified atmospheric packaging. Prolonged exposure leads to chilling injury and short duration exposure does not have significant effect of processing. So $7 \pm 2{ }^{\circ} \mathrm{C}$ and 10 minutes duration was found to be the best one.

\section{Permeability of packaging materials}

Three packaging film of LDPE and PP bags of varying thickness $152 \mu, 200 \mu$ and $400 \mu$ were tested for the permeability of gases, oxygen and Carbon dioxide using a permeability tester (M/s. PBI Dansensor, Lyssy Line of Permeability testers).

\section{Gas analysis}

The $\mathrm{O}_{2}$ and $\mathrm{CO}_{2}$ concentrations were measured with a MAP analyser (Make: PBI Dansensor Model: Checkmate II).

Every one hour the gas samples were drawn from the container through silicon rubber septum (fixed on the packaging material) using needle of the MAP analyser. With the recorded gas composition the respiration rate of oxygen and carbon dioxide were calculated. 


\section{Measurement of respiration rate}

Respiration is a metabolic process, which consists of oxidative breakdown of organic matter present in the cells such as starch, sugars, acids, fats, proteins into simpler molecules such as carbon dioxide and water along with concurrent production of energy and other molecules which can be used by the cell for synthetic reactions (Wills et.al., 1989). The extent of respiration can be measured by determining the amount of substrate loss, oxygen consumed, carbon dioxide liberated, heat produced and energy evolved (Pantastico et. al., 1975).

Respiration study was conducted in three steps under ambient and refrigerated conditions.

Closed system without gas flushing, Permeable system without gas flushing and Permeable system with gas flushing

In the closed system PET (Polyethylene Teri phthalate) containers with 1.780 liters capacity were used. The top and bottom diameters, height of the container were $12.5,11.5$ and 17 $\mathrm{cm}$, respectively. A single hole of one $\mathrm{cm}$ diameter was made on the top of the lid. A silicon septum was fitted into the hole using brass fittings to draw gas samples for analysis.

The respiration rate can be calculated by the change in oxygen concentration with time when the commodity was stored in a closed container as given below (Cameron et.al., 1989).

$$
\begin{aligned}
& \mathrm{Ro}_{2}=\frac{\mathrm{y}^{\mathrm{ti}} \mathrm{O}_{2}-\mathrm{y}^{\mathrm{tf}} \mathrm{O}_{2} \times \mathrm{V}}{100 \times \mathrm{Mx}\left(\mathrm{t}_{\mathrm{f}}-\mathrm{t}_{\mathrm{i}}\right)} \\
& \mathrm{Ro}_{2}=\frac{\mathrm{y}^{\mathrm{tf}} \mathrm{Co}_{2}-\mathrm{y}^{\mathrm{ti}} \mathrm{co}_{2} \times \mathrm{V}}{100 \times \mathrm{Mx}\left(\mathrm{t}_{\mathrm{f}}-\mathrm{t}_{\mathrm{i}}\right)}
\end{aligned}
$$

Where,

$$
\begin{aligned}
& \mathrm{Ro}_{2} \text { and } \mathrm{RcO}_{2} \quad \text { - respiration rate, in } \\
& \text { terms of } \mathrm{O}_{2} \text { and } \mathrm{CO}_{2} \\
& \text { evolved respectively, } \\
& \mathrm{m}^{3} / \mathrm{kg} / \mathrm{h} \\
& \mathrm{V} \quad \text { - free volume inside the } \\
& \text { container } \\
& \mathrm{yo}_{2}{ }^{\mathrm{ti}} \text { and } \mathrm{yo}_{2}{ }^{\mathrm{tf}} \quad-\text { volumetric } \\
& \text { concentration of } \mathrm{O}_{2} \text { at } \\
& \text { initial and final time } \\
& \text { respectively, \% } \\
& \mathrm{yco}_{2}{ }^{\mathrm{ti}} \text { and } \mathrm{yco}_{2}{ }^{\mathrm{tf}} \text { - volumetric } \\
& \text { concentration of } \mathrm{CO}_{2} \\
& \text { at initial and final } \\
& \text { time respectively, } \% \\
& \text { M } \\
& t_{i} \text { and } t_{f} \\
& \text { - mass of the stored } \\
& \text { product, } \mathrm{kg} \\
& \text { - initial and final time } \\
& \text { respectively, } \mathrm{h}
\end{aligned}
$$

The respiration rate was calculated by the change in oxygen concentration with time when the commodity was stored in a polymeric film (LDPE) was given below (Lakakul et al., 1999).

$$
\begin{aligned}
& \mathrm{Ro}_{2}=\frac{\mathrm{Po}_{2} \times \mathrm{A}}{100 \times \mathrm{L} \times \mathrm{M}} \times\left(\mathrm{y}^{e} \mathrm{O}_{2}-\mathrm{yo}_{2}\right)--(3) \\
& \mathrm{Rco}_{2}=\frac{\mathrm{Pco}_{2} \times \mathrm{A}}{100 \times \mathrm{L} \times \mathrm{M}} \times\left(\mathrm{yco}_{2}-\mathrm{y}^{e} \mathrm{CO}_{2}\right)--(4)
\end{aligned}
$$

Where,

$\begin{array}{lll}\mathrm{A} & - \text { package surface area, } \mathrm{m}^{2} \\ \mathrm{~L} & - \text { package thickness, } \mathrm{m} \\ \mathrm{M} & - \text { mass of stored product, } \mathrm{kg} \\ \mathrm{Po}_{2} \text { and } & - \text { film permeability coefficient for } \\ \mathrm{PcO}_{2} & \mathrm{O}_{2} \text { and } \mathrm{CO}_{2} \text { respectively, } \mathrm{m}^{2} \mathrm{~s}^{-1} \\ \mathrm{y}^{\mathrm{e}} \mathrm{O}_{2} & -\begin{array}{l}\text { volumetric concentrations of } \mathrm{O}_{2} \\ \text { and } \mathrm{yo}_{2}\end{array} & \begin{array}{l}\text { outside and inside the package, } \\ \text { respectively, } \%\end{array}\end{array}$




\section{Storage study}

Storage study was conducted based on the optimized product volume ratio 1:8. LDPE film of thickness $152 \mu$ was selected which has low permeability to oxygen. The gas composition of 5 per cent $\mathrm{O}_{2}, 5$ per cent $\mathrm{CO}_{2}$ and 90 per cent $\mathrm{N}_{2}$ was chosen as best composition for storing mint leaves under MAP. All the parameters were analysed based on the statistical analysis using AGRES. The leaves were stored until they get spoiled. During the storage period, physiological, physical, bio-chemical and microbiological studies (Atmosphere composition, Colour, Physiological loss in weight (PLW), Chlorophyll, Beta-carotene and Microbial Analysis) were carried out to compare the results with the fresh leaves. Based on the results, the shelf life of mint leaves under modified atmosphere packaging was determined.

\section{Statistical analysis}

Statistical analysis was carried out to study the effect of different parameters (Pretreatments, storage conditions and product to free volume ratio) on all the dependent variables. Analysis of variance (ANOVA) was conducted with Factorial Completely Randomized block Design (FCRD) using the statistical software AGRES.

\section{Results and Discussion}

The experimental results of respiration rate of mint leaves, change in oxygen and carbon dioxide concentration in the pretreatments and storage temperatures are discussed. The quality aspects of the green leaves such as physiological, physical, chemical, microbiological and shelf life on the final quality of the modified atmosphere packaged mint leaves are also discussed based on the results obtained from the experiments.

\section{Physicochemical and microbial analysis for fresh mint leaves}

The physicochemical parameters such as moisture content, colour value, chlorophyll content and $\beta$-carotene for the fresh mint leaves were analyzed and presented in table 4 and the results of microbial analysis in table 5. From the above results it is clear that the fungal population was lower than the bacterial population. This may be due to the quality of water used for irrigating the crop.

\section{Selection of packaging material}

Packaging material is optimized based on the permeability. The permeability of Low Density Poly Ethylene (LDPE) and Poly Propylene (PP) packaging materials of different thickness were assessed and selected for the study based on their permeability rate. The permeability of the packaging materials is given in figure 2 .

From the figure the maximum and minimum permeability to oxygen was observed for LDPE - 3 (2392 $\mathrm{ml} / \mathrm{m}^{2} /$ day) and LDPE -1 $\left(1067 \mathrm{ml} / \mathrm{m}^{2} /\right.$ day). LDPE-1 was selected as the packaging material, since it has less permeability to oxygen $\left(1067 \mathrm{ml} / \mathrm{m}^{2} /\right.$ day $)$ which was desirable for the study. More permeability to oxygen results in more availability of oxygen in the head space which increases respiration rate and results in decay of the product.

\section{Determination of respiration rate under closed system}

During respiration, $\mathrm{O}_{2}$ is consumed and $\mathrm{CO}_{2}$ is produced as the result of metabolic activity. Meyer et al., (1973) reported that during respiration oxygen is taken in by plants and break the organic reserves to simpler molecules of $\mathrm{CO}_{2}$ and water with release of energy. 
The respiration study using closed system without gas flushing for mint leaves revealed that under ambient condition the respiration rate was more than the refrigerated condition. The result clearly shows that the temperature is the most important external factor influencing the respiration. Biological reactions generally increase by two or threefold for every $10^{\circ} \mathrm{C}$ rise in temperature within the range of temperatures normally encountered in the distribution and marketing chain (Zagory and Kader, 1988).

Table 1 states that the minimum $\mathrm{RRO}_{2}$ was $0.1498 \mathrm{~m}^{3} / \mathrm{kg} \mathrm{h}$ under ambient condition and it was $0.0079 \mathrm{~m}^{3} / \mathrm{kg} \mathrm{h}$, due to lesser oxygen utility for respiration under refrigeration condition. This is due to less metabolic activity). Control with the product to free volume ratio of 1:8 was found to be effective in reducing the respiration rate under both the conditions. The $\mathrm{RRCO}_{2}$ under ambient and refrigerated conditions ranged from 0.1008 to $0.1072 \mathrm{~m}^{3} / \mathrm{kg} \mathrm{h}$ for the pre-cooled and control samples with the product to free volume ratio 1:8 after12 hours and between 0 - 0.1106 $\mathrm{m}^{3} / \mathrm{kg}$ h. Smyth et al., (1998) has also reported a rapid decrease of respiration rate over time for cut iceberg lettuce at $5^{\circ} \mathrm{C}$.

\section{Determination of respiration rate under permeable system without gas flushing}

From table 2 it was clear that the respiration rate $\mathrm{RRO}_{2}$ of mint kept under two different temperatures vary greatly. Under ambient condition the maximum value for respiration rate attained after 3 hours, for the product volume ratio of $1: 8$ was $0.2570 \mathrm{~m}^{3} / \mathrm{kg} \mathrm{h}$ and the lowest value measured was $0.0514 \mathrm{~m}^{3} / \mathrm{kg}$ h. For samples kept under refrigerated condition the lowest $\mathrm{RRO}_{2}$ was $0.0218 \mathrm{~m}^{3} / \mathrm{kg}$ h. Higher the temperature higher the respiration rate (Iqbal et al., 2004).

The $\mathrm{RRCO}_{2}$ of mint under refrigerated condition recorded the lowest value $(0.0656$ $\mathrm{m}^{3} / \mathrm{kg} \mathrm{h}$ ). Respiration rate decreased with a decrease in $\mathrm{O}_{2}$ concentration and temperature, and increased with a decrease in $\mathrm{CO}_{2}$ concentration (Fonseca et al., 2002).

\section{Respiration rate using permeable system with gas flushing}

It was observed from table 3 that respiration rate $\left(\mathrm{RRO}_{2}\right)$ under ambient condition was found to be minimum after 9 hours for the gas composition $\left(\mathrm{O}_{2}-5 \%, \mathrm{CO}_{2}-5 \%\right.$ and $\left.\mathrm{N}_{2}-90 \%\right)$. The lowest value of respiration rate was 0.108 $\mathrm{m}^{3} / \mathrm{kg} \mathrm{h}$ and was due to less oxygen availability in the head space provided. The lowest respiration rate under refrigerated condition was $0.104 \mathrm{~m}^{3} / \mathrm{kgh}$. The $\mathrm{RRCO}_{2}$ recorded a minimum value $\left(0.201 \mathrm{~m}^{3} / \mathrm{kg} \mathrm{h}\right)$ for the above said gas composition under low temperature storage. The results are same as the results obtained by Fonseca et al., (2002).

\section{Optimization of gas composition}

The respiration rate decreased with the decrease in temperature due to less reaction rate at lower temperatures (Zhang et al., 2003). Kader et al., (1992) reported that 3-5 per cent of $\mathrm{O}_{2}$ and 4-5 per cent of $\mathrm{CO}_{2}$ are more suitable for maintaining the quality and extending shelf life of fresh-cut produces at refrigerated condition. The gas composition was optimized based on the respiration rate under ambient and refrigerated conditions. The lowest respiration rate of $\mathrm{O}_{2}$ obtained in the refrigerated system for mint leaves was $0.104 \mathrm{~m}^{3} / \mathrm{kg} \mathrm{h}$ for the gas composition containing 5 per cent $\mathrm{O}_{2}, 5$ per cent $\mathrm{CO}_{2}$ and 90 per cent $\mathrm{N}_{2}$ as mentioned in table 3 From the results, it was concluded that in gas flushed permeable system, the respiration rate of $\mathrm{O}_{2}$ and $\mathrm{CO}_{2}$ under refrigeration condition showed lesser respiration rate compared to ambient condition. The respiration rate decreased with the decrease of temperature (Li and Zhang, 2008). 
Table.1 Effect of Product volume ratio, pretreatments and duration on respiration rate of mint under ambient and refrigerated condition for closed system

\begin{tabular}{|c|c|c|c|c|c|c|}
\hline \multirow{2}{*}{$\begin{array}{l}\text { Product volume } \\
\text { ratio }\end{array}$} & \multirow{2}{*}{ Treatment } & \multirow{2}{*}{ Duration,h } & \multicolumn{2}{|c|}{ Ambient condition } & \multicolumn{2}{|c|}{$\begin{array}{l}\text { Refrigerated } \\
\text { condition }\end{array}$} \\
\hline & & & $\mathbf{R o}_{2}$ & $\mathrm{Rco}_{2}$ & $\mathrm{Ro}_{2}$ & $\mathrm{RCO}_{2}$ \\
\hline \multirow{12}{*}{$1: 17$} & \multirow{4}{*}{ control } & 3 & 0.3248 & 0.1848 & 0.0336 & 0.0504 \\
\hline & & 6 & 0.2352 & 0.1400 & 0.0336 & 0.0336 \\
\hline & & 9 & 0.1960 & 0.1232 & 0.0672 & 0.0168 \\
\hline & & 12 & 0.1820 & 0.1190 & 0.0336 & 0.0504 \\
\hline & \multirow{4}{*}{ Pre chilling } & 3 & 0.3024 & 0.1736 & 0.0336 & 0.0336 \\
\hline & & 6 & 0.2240 & 0.1400 & 0.0336 & 0.0504 \\
\hline & & 9 & 0.1978 & 0.1232 & 0.0672 & 0.0336 \\
\hline & & 12 & 0.1652 & 0.1078 & 0.0504 & 0.0672 \\
\hline & \multirow{4}{*}{ Pre cooling } & 3 & 0.3248 & 0.1848 & 0.0504 & 0.0336 \\
\hline & & 6 & 0.2352 & 0.1428 & 0.0336 & 0.0336 \\
\hline & & 9 & 0.1978 & 0.1288 & 0.0504 & 0.0168 \\
\hline & & 12 & 0.1680 & 0.1148 & 0.0336 & 0.0504 \\
\hline \multirow{12}{*}{$1: 11$} & \multirow{4}{*}{ control } & 3 & 0.2071 & 0.1380 & 0.0327 & 0.0218 \\
\hline & & 6 & 0.1908 & 0.1298 & 0.0327 & 0.0218 \\
\hline & & 9 & 0.1647 & 0.1114 & 0.1526 & 0.0436 \\
\hline & & 12 & 0.1498 & 0.1008 & 0.0218 & 0.0436 \\
\hline & \multirow{4}{*}{ Pre chilling } & 3 & 0.2289 & 0.1453 & 0.0436 & 0.0218 \\
\hline & & 6 & 0.2197 & 0.1435 & 0.0218 & 0.0327 \\
\hline & & 9 & 0.1889 & 0.1162 & 0.1526 & 0.0436 \\
\hline & & 12 & 0.1644 & 0.1153 & 0.0436 & 0.0327 \\
\hline & \multirow{4}{*}{ Pre cooling } & 3 & 0.2107 & 0.1344 & 0.0654 & 0.0218 \\
\hline & & 6 & 0.1962 & 0.1308 & 0.0218 & 0.0218 \\
\hline & & 9 & 0.1683 & 0.1114 & 0.0763 & 0.0545 \\
\hline & & 12 & 0.1507 & 0.1072 & 0.0218 & 0.0218 \\
\hline \multirow{12}{*}{$1: 8$} & \multirow{4}{*}{ control } & 3 & 0.2449 & 0.1501 & 0.0316 & 0.0474 \\
\hline & & 6 & 0.2119 & 0.1422 & 0.0158 & 0 \\
\hline & & 9 & 0.1825 & 0.1211 & 0.0237 & 0.0237 \\
\hline & & 12 & 0.2225 & 0.1725 & 0.0079 & 0.0237 \\
\hline & \multirow{4}{*}{ Pre chilling } & 3 & 0.2449 & 0.1580 & 0.0474 & 0.1027 \\
\hline & & 6 & 0.2133 & 0.1501 & 0.0158 & 0.0158 \\
\hline & & 9 & 0.1843 & 0.1299 & 0.0079 & 0.0237 \\
\hline & & 12 & 0.2185 & 0.1665 & 0.0079 & 0 \\
\hline & \multirow{4}{*}{ Pre cooling } & 3 & 0.2370 & 0.1553 & 0.0395 & 0.1106 \\
\hline & & 6 & 0.2067 & 0.1462 & 0.0158 & 0.0079 \\
\hline & & 9 & 0.1808 & 0.1281 & 0.0237 & 0.0158 \\
\hline & & 12 & 0.2172 & 0.1685 & 0.0079 & 0 \\
\hline
\end{tabular}


Table.2 Effect of Product volume ratio, pretreatments and duration on respiration rate of mint under ambient and refrigerated condition for permeable system

\begin{tabular}{|c|c|c|c|c|c|c|}
\hline \multirow{2}{*}{$\begin{array}{l}\text { Product } \\
\text { volume ratio }\end{array}$} & \multirow{2}{*}{ Treatment } & \multirow{2}{*}{ Duration,h } & \multicolumn{2}{|c|}{ Ambient condition } & \multicolumn{2}{|c|}{$\begin{array}{l}\text { Refrigerated } \\
\text { condition }\end{array}$} \\
\hline & & & $\mathrm{Ro}_{2}$ & $\mathrm{RcO}_{2}$ & $\mathbf{R o}_{2}$ & $\mathrm{Rco}_{2}$ \\
\hline \multirow{12}{*}{$1: 17$} & \multirow{4}{*}{ control } & 3 & 0.1103 & 0.3007 & 0.0568 & 0.1730 \\
\hline & & 6 & 0.0941 & 0.2496 & 0.0405 & 0.1362 \\
\hline & & 9 & 0.0827 & 0.2208 & 0.0373 & 0.1428 \\
\hline & & 12 & 0.0697 & 0.1851 & 0.0466 & 0.1532 \\
\hline & \multirow{4}{*}{ Pre chilling } & 3 & 0.1557 & 0.3858 & 0.0519 & 0.1305 \\
\hline & & 6 & 0.1241 & 0.2886 & 0.0349 & 0.0972 \\
\hline & & 9 & \begin{tabular}{|l}
0.1081 \\
\end{tabular} & 0.2539 & 0.0346 & 0.1026 \\
\hline & & 12 & 0.0941 & 0.2241 & 0.0332 & 0.1124 \\
\hline & \multirow{4}{*}{ Pre cooling } & 3 & 0.1265 & 0.3362 & 0.0795 & 0.1943 \\
\hline & & 6 & 0.1070 & 0.2745 & 0.0616 & 0.1681 \\
\hline & & 9 & 0.0930 & 0.2444 & 0.0546 & 0.1522 \\
\hline & & 12 & 0.0807 & 0.2117 & 0.0474 & 0.1461 \\
\hline \multirow{12}{*}{$1: 11$} & \multirow{4}{*}{ control } & 3 & \begin{tabular}{|l|}
0.09504 \\
\end{tabular} & 0.2622 & 0.0454 & 0.1297 \\
\hline & & 6 & 0.0772 & 0.2092 & 0.0319 & 0.0862 \\
\hline & & 9 & 0.0598 & 0.1663 & 0.0310 & 0.0953 \\
\hline & & 12 & 0.0524 & 0.1437 & 0.0311 & 0.0999 \\
\hline & \multirow{4}{*}{ Pre chilling } & 3 & 0.1350 & 0.3569 & 0.0421 & 0.1060 \\
\hline & & 6 & 0.1064 & 0.2708 & 0.0292 & 0.0743 \\
\hline & & 9 & 0.0918 & 0.2310 & 0.0274 & 0.0795 \\
\hline & & 12 & 0.0791 & 0.2005 & 0.0265 & 0.0703 \\
\hline & \multirow{4}{*}{ Pre cooling } & 3 & 0.1069 & 0.2954 & 0.0518 & 0.1155 \\
\hline & & 6 & 0.0907 & 0.2447 & 0.0432 & 0.1075 \\
\hline & & 9 & 0.0821 & 0.2215 & 0.0360 & 0.0953 \\
\hline & & 12 & 0.0689 & 0.1827 & 0.0324 & 0.0963 \\
\hline \multirow{12}{*}{$1: 8$} & \multirow{4}{*}{ control } & 3 & 0.0842 & 0.2357 & 0.0454 & 0.1328 \\
\hline & & 6 & 0.0717 & 0.1960 & 0.0304 & 0.0948 \\
\hline & & 9 & 0.0605 & 0.1638 & 0.0273 & 0.0857 \\
\hline & & 12 & 0.0514 & 0.1415 & 0.0267 & 0.0944 \\
\hline & \multirow{4}{*}{ Pre chilling } & 3 & 0.1029 & 0.28187 & 0.0316 & 0.0866 \\
\hline & & 6 & 0.0786 & 0.2226 & 0.0271 & 0.0664 \\
\hline & & 9 & \begin{tabular}{|l|}
0.0705 \\
\end{tabular} & 0.1874 & 0.0243 & 0.0656 \\
\hline & & 12 & 0.0610 & 0.1645 & 0.0219 & 0.0669 \\
\hline & \multirow{4}{*}{ Pre cooling } & 3 & 0.0948 & 0.2570 & 0.0429 & 0.1115 \\
\hline & & 6 & 0.0818 & 0.2208 & 0.0304 & 0.0770 \\
\hline & & 9 & 0.0753 & 0.1993 & 0.0251 & 0.0691 \\
\hline & & 12 & 0.0640 & 0.1699 & 0.0233 & 0.0678 \\
\hline
\end{tabular}


Table.3 Effect of Product volume ratio, pretreatments and duration on respiration rate of mint under ambient and refrigerated condition for permeable system with gas flushing

\begin{tabular}{|c|c|c|c|c|c|}
\hline \multirow{2}{*}{$\begin{array}{l}\text { Gas } \\
\text { composition }\end{array}$} & \multirow{2}{*}{ Duration-h } & \multicolumn{2}{|c|}{ Ambient condition } & \multicolumn{2}{|c|}{ Refrigerated condition } \\
\hline & & $\mathbf{R O}_{2}$ & $\mathrm{RCO}_{2}$ & $\mathbf{R O}_{2}$ & $\mathrm{RCO}_{2}$ \\
\hline \multirow{3}{*}{$\begin{array}{l}\mathrm{O} 2-3 \% \text {, } \\
\mathrm{CO} 2-5 \% \text { and } \\
\mathrm{N} 2-92 \%\end{array}$} & 3 & 0.3029 & 0.4878 & 0.3029 & 0.4878 \\
\hline & 6 & 0.1620 & 0.2829 & 0.1612 & 0.2936 \\
\hline & 9 & 0.1118 & 0.2147 & 0.1118 & 0.2265 \\
\hline \multirow{3}{*}{$\begin{array}{l}\mathrm{O} 2-4 \% \\
\mathrm{CO} 2-5 \% \text { and } \\
\mathrm{N} 2-91 \%\end{array}$} & 3 & 0.3029 & 0.4878 & 0.2916 & 0.4594 \\
\hline & 6 & 0.1620 & 0.2829 & 0.1539 & 0.2794 \\
\hline & 9 & 0.1118 & 0.2147 & 0.1107 & 0.2194 \\
\hline \multirow{3}{*}{$\begin{array}{l}\mathrm{O} 2-5 \% \\
\mathrm{CO} 2-5 \% \text { and } \\
\mathrm{N} 2-90 \%\end{array}$} & 3 & 0.2770 & 0.4807 & 0.2803 & 0.4452 \\
\hline & 6 & 0.1515 & 0.2936 & 0.1474 & 0.2581 \\
\hline & 9 & 0.1080 & 0.2194 & 0.1042 & 0.2005 \\
\hline
\end{tabular}

Table.4 Physicochemical qualities of fresh mint leaves

\begin{tabular}{|l|c|c|c|c|c|}
\hline \multicolumn{7}{|l|}{ Physicochemical qualities of fresh mint leaves } \\
\hline $\begin{array}{l}\text { Moisture content } \\
\text { (\%, wb) }\end{array}$ & \multicolumn{3}{|c|}{ Colour value } & $\begin{array}{c}\text { Chlorophyll } \\
\text { content (mg/g) }\end{array}$ & $\begin{array}{c}\beta \text {-carotene (mg } \\
\text { /g) }\end{array}$ \\
\cline { 2 - 5 } & L & a & b & 48.30 \\
\hline 86.7 & 42.24 & -12.75 & 22.34 & 1.40 & 48.30 \\
\hline
\end{tabular}

Table.5 Microbial analysis of fresh mint leaves

\begin{tabular}{|c|c|c|}
\hline \multicolumn{3}{|c|}{ Microbial analysis of fresh mint leaves } \\
\hline Replication & $\begin{array}{c}\text { Bacterial } \\
\text { population } \\
\mathbf{1} 10^{5} \text { cfu/mg }\end{array}$ & $\begin{array}{c}\text { Fungi population } \\
\mathbf{1 0} \mathbf{~} \mathbf{c f u} / \mathbf{m g}\end{array}$ \\
\hline I & 15 & 2 \\
\hline II & 5 & 1 \\
\hline III & 9 & 2 \\
\hline
\end{tabular}


Table.6 Effect of storage period on colour value for mint leaves

\begin{tabular}{|l|c|c|c|c|c|c|}
\hline \multirow{2}{*}{$\begin{array}{l}\text { Storage } \\
\text { days }\end{array}$} & \multicolumn{6}{|c|}{ Colour value } \\
\cline { 2 - 7 } & \multicolumn{2}{|c|}{ Ambient condition } & \multicolumn{2}{c|}{ Refrigerated condition } \\
\cline { 2 - 7 } & L & a & b & L & a & b \\
\hline 0 & 40.24 & -12.75 & 22.34 & 40.24 & -12.75 & 22.34 \\
\hline 4 & 31.56 & -4.78 & 15.98 & 40.15 & -9.43 & 22.11 \\
\hline 8 & - & - & - & 39.72 & -10.1 & 23.1 \\
\hline 12 & - & - & - & 40.18 & -8.9 & 21.86 \\
\hline 16 & - & - & - & 37.28 & -8.71 & 22.45 \\
\hline 20 & - & - & - & 36.44 & -7.95 & 21.62 \\
\hline
\end{tabular}

Table.7 Effect of storage period on gas composition of mint leaves

\begin{tabular}{|c|c|c|c|c|c|c|c|c|c|c|}
\hline \multirow{3}{*}{$\begin{array}{l}\text { Storage } \\
\text { days }\end{array}$} & \multicolumn{5}{|c|}{ Ambient condition } & \multicolumn{5}{|c|}{ Refrigerated condition } \\
\hline & \multicolumn{3}{|c|}{ Gas composition \% } & \multirow{2}{*}{$\mathrm{RRO}_{2}$} & \multirow{2}{*}{$\mathrm{RRCO}_{2}$} & \multicolumn{3}{|c|}{ Gas composition \% } & \multirow{2}{*}{$\mathrm{RRO}_{2}$} & \multirow{2}{*}{$\mathrm{RRCO}_{2}$} \\
\hline & $\mathbf{O}_{2}$ & $\mathrm{CO}_{2}$ & $\mathbf{N}_{2}$ & & & $\mathrm{O}_{2}$ & $\mathrm{CO}_{2}$ & $\mathbf{N}_{2}$ & & \\
\hline 0 & 4.8 & 5.3 & 89.9 & 0.0972 & 0.0639 & 4.7 & 5.2 & 90.1 & 0.01458 & 0.0426 \\
\hline 4 & 0 & 9.4 & 90.6 & 0.0025 & 0.0098 & 1.4 & 6 & 92 & 0.0018 & 0.0022 \\
\hline 8 & - & - & - & - & - & 0.4 & 8.4 & 91.2 & 0.0012 & 0.0037 \\
\hline 12 & - & - & - & - & - & 2 & 6.7 & 92.1 & 0.0008 & 0.0013 \\
\hline 16 & - & - & - & - & - & 0.9 & 8.1 & 91.2 & 0.0005 & 0.0017 \\
\hline 20 & - & - & - & - & - & 0.1 & 9.6 & 91 & 0.0005 & 0.0002 \\
\hline
\end{tabular}

Table.8 Microbial load on the $20^{\text {th }}$ day of storage

\begin{tabular}{lcc}
$\begin{array}{l}\text { Name of the green } \\
\text { leaf }\end{array}$ & $\begin{array}{l}\text { Bacterial population } \\
\mathbf{x} \mathbf{1 0}^{\mathbf{6}} \mathbf{c f u} / \mathbf{m g}\end{array}$ & $\begin{array}{l}\text { Fungal population } \\
\mathbf{x} \mathbf{1 0}^{4} \mathbf{c f u} / \mathbf{m g}\end{array}$ \\
\hline \multirow{2}{*}{ Mint leave } & I 13 & 3.0 \\
& II 15 & 4.0 \\
& III 14 & 4.0 \\
\hline
\end{tabular}

Methods of estimation of dependent variables

\begin{tabular}{|l|l|l|}
\hline S.No. & Dependent variables & Method adopted \\
\hline Physiological and physical properties \\
\hline 1. & Physiological loss in weight & PLW $(\%)=\frac{\text { Initial weight }- \text { Final weight }}{\text { Initial weight }} \times 100$ \\
\hline 2. & & Colour value \\
\hline Biochemical properties and microbial load \\
\hline 3. & Beta carotene & Ranganna (1979) \\
\hline 4. & Chlorophyll content & Ranganna (1979) \\
\hline 5. & Microbial load & Standard plate count method (Allen,1953) \\
\hline
\end{tabular}


Fig.1 Flow chart for modified atmosphere packaging of mint leaves

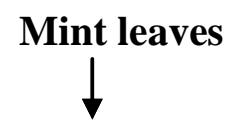

Trimming (removal of root, unwanted materials)

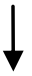

Washing (to remove soil particles)

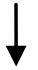

Shade drying (to remove surface moisture)

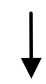

Weighing and bundling (50, 75 and $100 \mathrm{~g})$

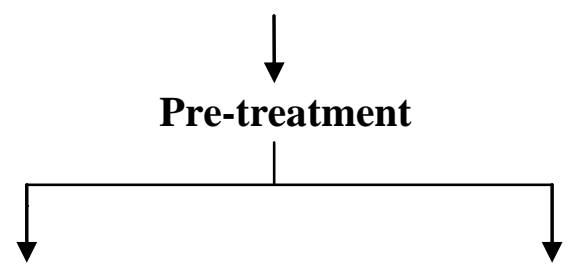

Pre-chilling

Pre-cooling

$\left(5^{\circ} \mathrm{C}, 10 \mathrm{~min}\right.$. in cold water $)$

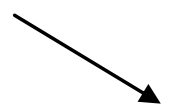

$\left(10^{\circ} \mathrm{C}, 10 \mathrm{~min}\right.$. in refrigeration)

Packing in LDPE bags
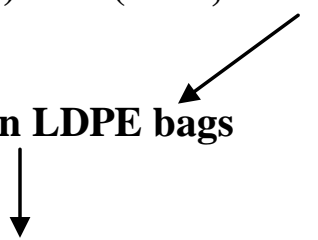

Gas flushing and sealing

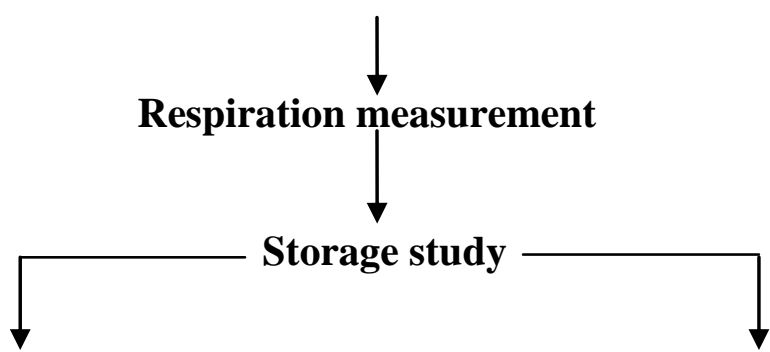

Refrigerated condition

Ambient condition 
Fig.2 Permeability of the packaging materials

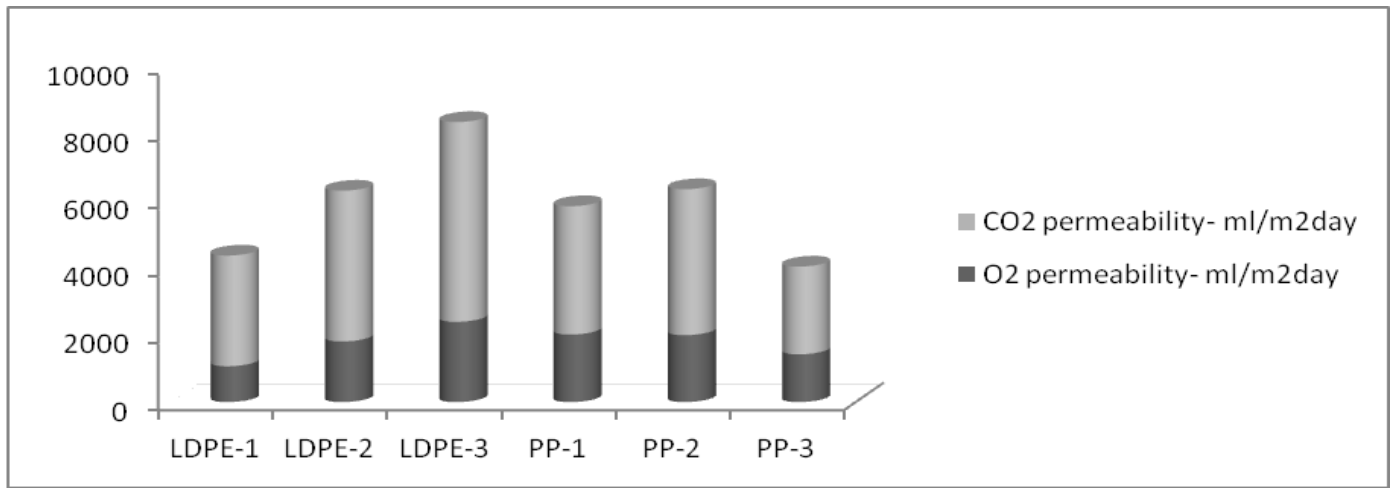

Fig.3 Physiological loss in weight of mint leaves during storage

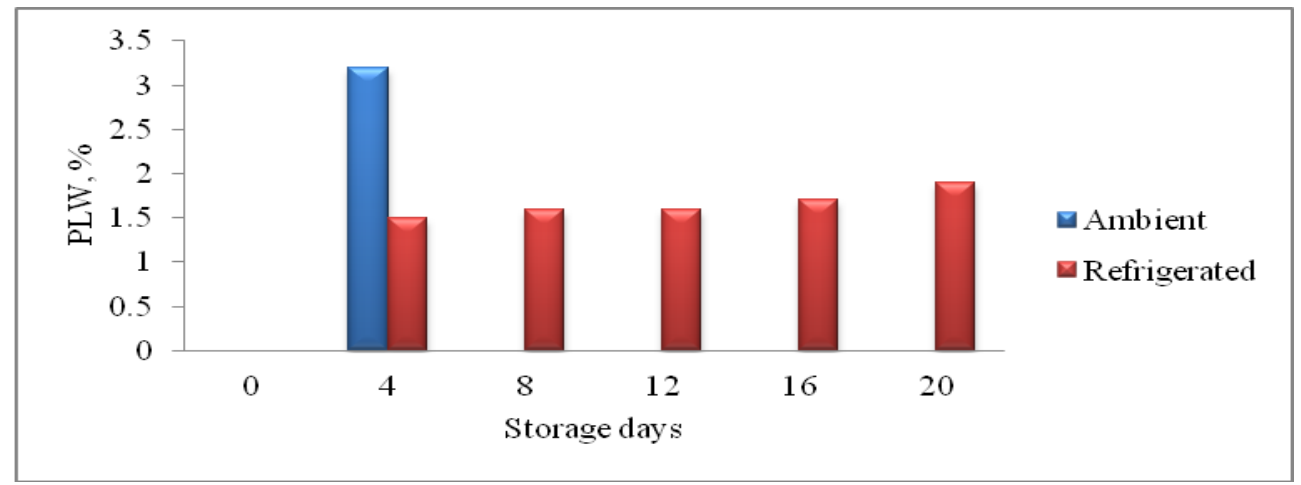

Fig.4 Change in respiration rate of $\mathrm{O}_{2}$ during storage of mint leaves

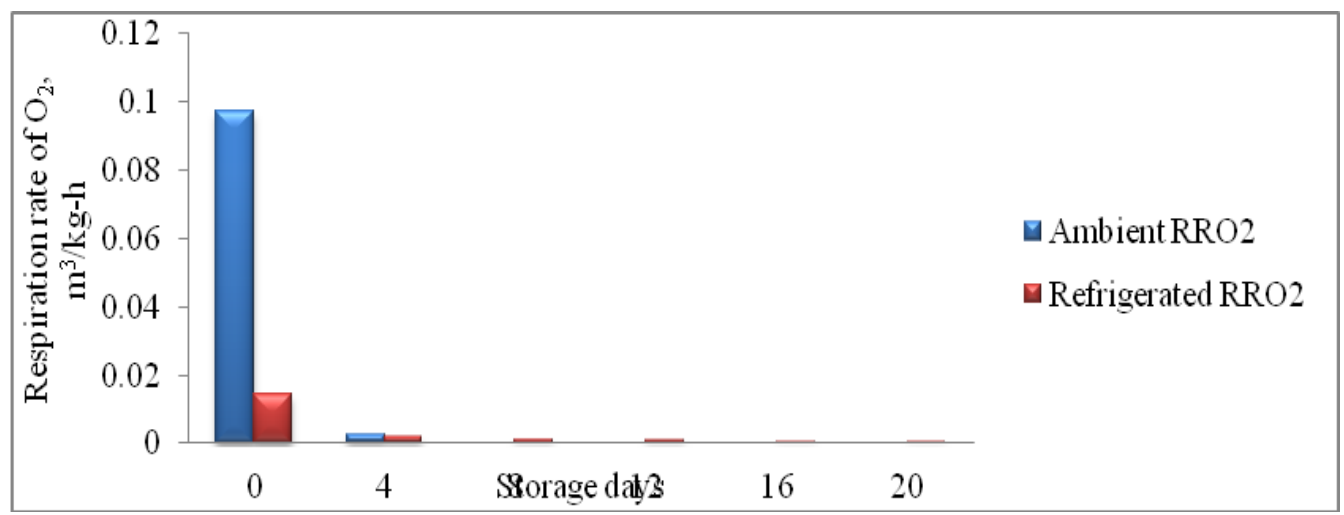


Fig.5 Change in respiration rate of $\mathrm{CO}_{2}$ during storage of mint leaves

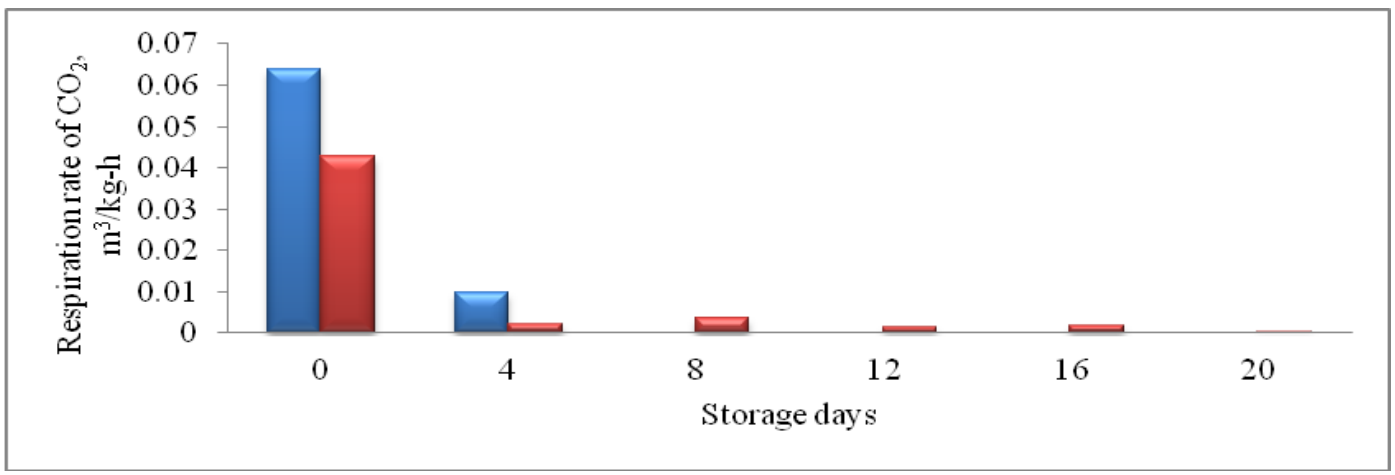

Fig.6 Change in chlorophyll content during storage of mint leaves

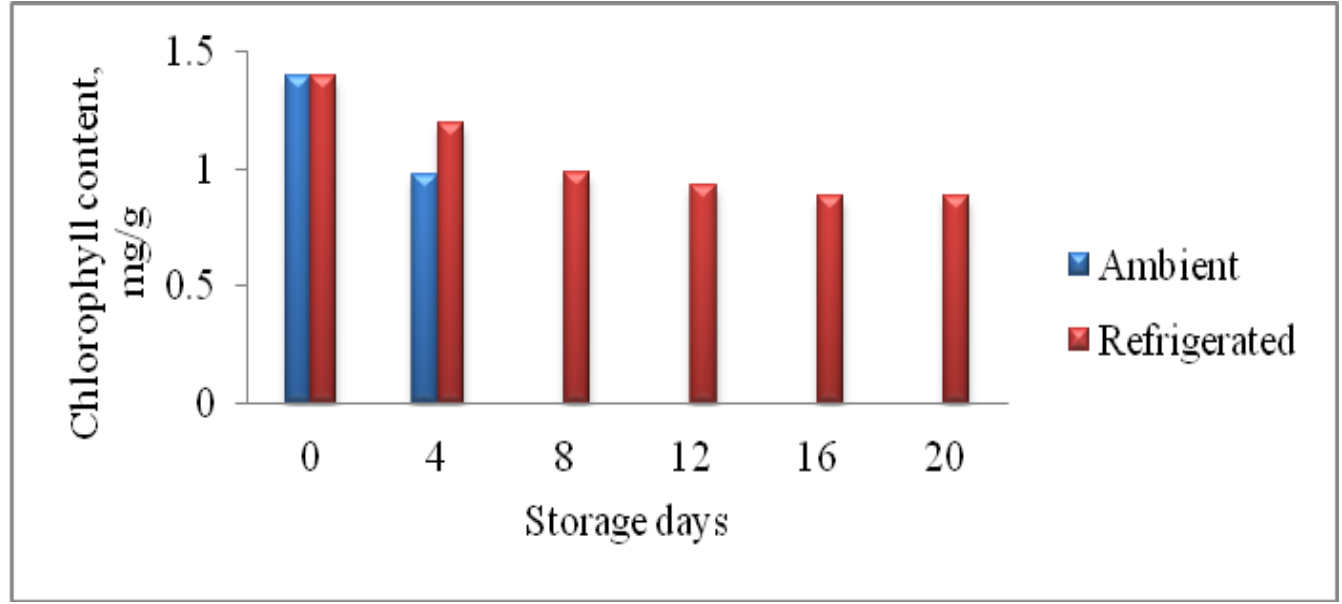

Fig.7 Change in $\beta$ - carotene content during storage of mint leaves

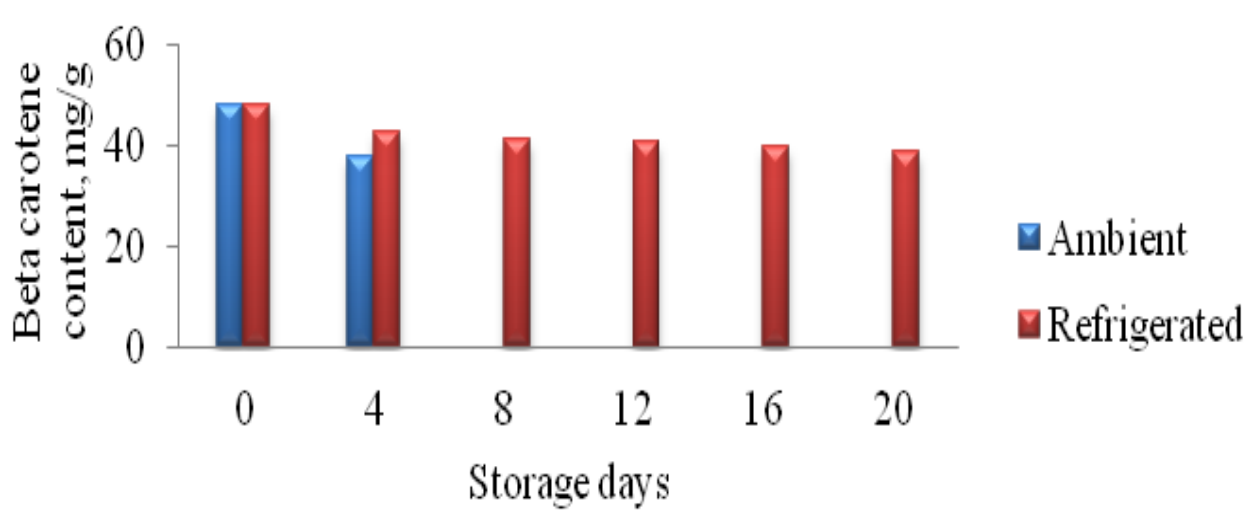


The PLW was less, the colour value, chlorophyll and beta carotene contents were retained much in the case of 5 per cent $\mathrm{O}_{2}, 5$ per cent $\mathrm{CO}_{2}$ and 90 per cent $\mathrm{N}_{2}$ gas composition. Hence, the composition was chosen for storage study along with pre cooling treatment and 1:8 as product to free volume ratio for mint leaves. The storage study was conducted under ambient condition and in refrigerated condition.

Effect of storage period on the physiological loss in weight of mint leaves (PLW)

It was inferred from figure 3 . The weight loss was gradual from the initial day of storage to final day. The weight loss of 1.9 per cent was observed during the $20^{\text {th }}$ day of storage for the sample kept under refrigerated condition. PLW was more under ambient condition than the refrigerated condition, and was reported as 3.2 per cent.

This was due higher temperature in the ambient atmosphere, which leads to high respiration than the refrigerated condition. The PLW may be mainly due to water loss as the product of respiration (Wills et al., 1989) and also due to transpiration water loss (Moleyar and Narasimhan, 1994) during the storage period.

\section{Effect of storage period on the colour value of mint leaves}

The colour of mint leaves indicates the freshness of the leaves during the storage period. The ' $L$ ' value represents the brightness of the leaves and from the table 6 , it was evident that the ' $L$ ' value of the mint leaves decreased from 40.24 to 36.44 on $20^{\text {th }}$ day of storage. There was no much variation in the ' $\mathrm{L}$ ' value of the leaves during storage. The ' $a$ ' value of the mint leaves under ambient condition changed to a large extent because the leaves have started decaying on the $4^{\text {th }}$ day itself. The refrigerated stored leaves have shown a constant decrease in the green colour. At the $20^{\text {th }}$ day of storage the 'a' value was -7.95 . The ' $b$ ' value changed to $a$ lesser extent during the storage period. The ' $b$ ' at the beginning of storage was about 22.34 and at the $20^{\text {th }}$ day was 21.62 respectively. Higher temperature inside the package degrades the colour of the mint leaves due to the bleaching or surface burning. Similar results were also reported by Kader et al., (2002).

\section{Effect of storage period on the gas} composition of mint leaves

Temperature had significant impact on the respiration rate. At ambient condition the samples got spoiled after 4 days, whereas in refrigeration, the samples were in good condition up to 20 days, since $\mathrm{O}_{2}$ consumption and $\mathrm{CO}_{2}$ production were less due to low metabolic activity. Fonseca et al., (2002) reported that at lower temperature the oxygen consumption and carbon dioxide generation were less. As per the general statement in the case of respiration the oxygen concentration decreases and carbon dioxide concentration increases.

The gas composition inside the gas flushed mint leaves also follows the same trend. From table 7 it was clear that under ambient condition $\left(30^{\circ} \mathrm{C}\right)$ decrease in $\mathrm{O}_{2}$ concentration results an increase in $\mathrm{CO}_{2}$ level. Under refrigerated storage condition the $\mathrm{O}_{2}$ concentration was decreasing up to $8^{\text {th }}$ day increasing on $12^{\text {th }}$ day and was about 2 per cent, later on declines to 0.1 per cent on $20^{\text {th }}$ day. Regarding $\mathrm{CO}_{2}$ concentration it decreased to 6.7 per cent and increased to 9.6 per cent on $20^{\text {th }}$ day of storage. The fluctuation in gas concentration during storage was mainly due to permeability of the packaging material to $\mathrm{O}_{2}$ and $\mathrm{CO}_{2}$ (Figs. 4 and 5). 
Effect of gas composition on the respiration rate on mint leaves

The respiration rate was found to be high under ambient condition than refrigerated storage. It is evident from table 7 that $\mathrm{RRO}_{2}$ value at $30^{\circ} \mathrm{C}$ was $0.097 \mathrm{~m}^{3} / \mathrm{kg} \mathrm{h}$ and reduced to $0.0018 \mathrm{~m}^{3} / \mathrm{kg} \mathrm{h}$ on the $4^{\text {th }}$ day. The leaves have started decaying after this period under ambient condition. In the case of refrigerated condition the initial value of $\mathrm{RRO}_{2}$ was $0.0146 \mathrm{~m}^{3} / \mathrm{kg} \mathrm{h}$ and reduced to $0.0005 \mathrm{~m}^{3} / \mathrm{kg}$ $\mathrm{h}$. This was due to lower metabolic activity under this temperature.

The respiration rate of carbon dioxide followed the same trend as $\mathrm{RRO}_{2}$. From table 7 it is clear that the $\mathrm{RRCO}_{2}$ was 0.0639 in the initial period and reduced to $0.002 \mathrm{~m}^{3} / \mathrm{kg} \mathrm{h}$ at the fourth day of storage. Similarly in the refrigerated condition it was reduced to $0.0002 \mathrm{~m}^{3} / \mathrm{kg}$ h on $20^{\text {th }}$ day from $0.026 \mathrm{~m}^{3} / \mathrm{kg}$ $\mathrm{h}$ in the beginning.

Temperature is the most important external factor influencing the respiratory activity of fruit and vegetables (Zagory and Kader, 1988). Watada et al., (1996) stated that low $\mathrm{O}_{2}$ and elevated $\mathrm{CO}_{2}$ atmospheres together with low storage temperature reduce the product respiration rate. Fonseca et al., (2002) also reported the increase of shelf life of was found in shredded galega kale when stored under gas flushed samples.

Effect of gas composition on the chlorophyll and $\beta$ - carotene content of mint leaves

From figure 6 it is clear that the chlorophyll content of the sample stored under ambient condition reduced to $0.971 \mathrm{mg} / \mathrm{g}$ against its initial values. Under refrigerated condition it varied between $1.4 \mathrm{mg} / \mathrm{g}-0.883 \mathrm{mg} / \mathrm{g}$. The chlorophyll content decreased with increase of storage period. Roura et al., (2000) reported that processing induced the decrease of chlorophyll content during storage in swiss chard leaves.

In the fresh mint leaves the $\beta$ - carotene content was $48.3 \mathrm{mg} / \mathrm{g}$. The figure 7 stated that there was a sudden decrease in the value to about $37.81 \mathrm{mg} / \mathrm{g}$ under ambient condition. In the refrigerated condition the value on the $20^{\text {th }}$ day was $38.67 \mathrm{mg} / \mathrm{g}$.

\section{Effect of gas composition on the microbial population of mint leaves}

Maintaining the quality of the food product during storage was mainly due to inhibition of growth of spoilage microorganisms and in most cases the condition chosen were that those reduce the microbial growth. Microbial food spoilage was characterized by undesirable sensory changes to the odour, colour, flavour and sometimes texture of the food, making it inedible or unsaleable. Generally low $\mathrm{O}_{2}$ and high $\mathrm{CO}_{2}$ with low temperature condition was selected for safe food products in MAP.

The low level of oxygen may inhibit the surface growth of pathogenic anaerobic bacteria particularly Clostridium botulinum but it would not prevent anaerobic condition present on the body of the product (Hotchkiss, 1988). It is noted that the bacterial and fungal population during the storage period are within the limits (Table 8).

In the closed system the observed minimum respiration rate under the refrigerated condition was between $0-0.0079 \mathrm{~m}^{3} / \mathrm{kgh}$ and for permeable system without gas flushing minimum respiration rate was 0.02187 $\mathrm{m}^{3} / \mathrm{kgh}$. In the permeable system with gas flushing minimum respiration rate observed was $0.1042 \mathrm{~m}^{3} / \mathrm{kgh}$, for the gas composition 5 per cent $\mathrm{O}_{2}, 5$ per cent $\mathrm{CO}_{2}$ and 90 per cent $\mathrm{N}_{2}$. 
The physiological loss in weight observed was less under refrigerated condition than in ambient condition for coriander and mint leaves. The colour value, chlorophyll and beta carotene content of mint leaves were not altered significantly up to 20 days. The microbial population for was within the permissible level after 20 days. Storage at refrigerated condition with modified atmosphere packaging was effective in extending the shelf life of mint leaves to 20 days compared to four days under the ambient condition.

\section{References}

Aguilera, R. and J.C.Olivera. 2009. Review of design engineering methods and applications of active and modified atmosphere packaging systems. Food Eng.Rev. 1:66-83.

Aharoni, N., A. Reuveni and O. Dvir. 1989. Modified atmospheres in film packages delay senescense and decay of green vegetables and herbs. Acta Hort. 258:255-262.

Allen, O.N. 1953. Experiments in Soil Bacteriology. Burgess Co., Minneapolis, Minn. 69-70.

Cameron, A. C., W. Boylan-Pett and J. Lee. 1989. Design of modified atmosphere packaging systems: modeling oxygen concentrations within sealed packages of tomato fruits. Journal of Food Science 54: 1413-1416.

Cantwell, M.I and M.S.Reid. 1993. Postharvest physiology and handling of fresh culinary herbs. J.herbs, spices, Medicinal Plants 1: 93-127.

Fonseca, S.C., F.A.R. Oliveira, J.M. Frias, J.K. Brecht and K.V. Chau. 2002. Modelling respiration rate of shredded Galega kale for development of modified atmosphere packaging. Journal of Food Engineering. 54 (4):
$299-307$.

Gafney, J.J and C.D. Baird. 1976. A numerical procedure for calculating heat transfer in bulk loads of fruits or vegetables. ASHRAE Transactions 82:525-540.

Guevara,J.C., E.M. Yahia, E. Brito de la Fuente and S.P. Biserka. 2003. Effects of elevated concentrations of $\mathrm{CO}_{2}$ in modified atmosphere packaging on the quality of prickly pear cactus stems (Opuntia spp.). Post-harvest Biological Technology 29: 167-176.

Hotchkiss, J.H. 1988. Experimental Approaches to determining the safety of food packaged in modified atmospheres. Food Technology 42: 55 64.

Iqbal, T., F.A.R. Oliveira and J. Kerry. 2004. Effect of temperature and cutting on the respiration rate of mushrooms. Presentation at annual meeting of Institute of Food Technologist. Las Vegas Nevada USA. 12-16.

Janick J. 1986. Horticultural science. 4th Ed. New York: Free- man WH; p. 550-551.

Jayas, D.S. and S. Jeyamkondan. 2002. Review Paper - Modified atmosphere storage of grains, meats, fruits and vegetables. Biosystems Engineering. 82(3): 235-251.

Kader, A.A. 2002. Postharvest Technology of Horticultural Crops. $\quad 3^{\text {rd }}$ edition.University of California. ISBN: 1-879906-51-1.

Kader, A.A., R.F.Karmine, F.G.Mitchell, N.F.Sommer and J.F.Thompson. 1992. Postharvest technology of horticultural crops. 2nd Ed. Berkeley (CA): University of California Press, Special publication 3311.

Lakakul, R., Beaudry, R. M and Hernandez, R. J. (1999). Modeling respiration of apple slices in modified-atmosphere packages. Journal of Food Science 64: 105-110. 
Li, T. and M. Zhang. 2008. Effects of modified atmosphere packaging with various sizes of silicon gum film window on the storage and the modelling of its respiration rate. Packaging Technology and Science. 21: 13-23.

Meyer, B. S., D.B. Anderson, R.H. Bohling and D.G. Fratianne. 1973. Introduction to plant physiology (2 $2^{\text {nd }} \quad$ Ed.). Princeton, New Jersey, USA: Van Nostrand.

Moleyar, K. and B. Narasimhan. 1994. Lightly processed fruits and vegetables. Journal of Horticulture Science. 30 (1): 14.

Pantastico, E.R.B., T.K. Chattopadhyay and H. Subramanyan. 1975. Storage and commercial storage operations. In: Postharvest physiology, handling and utilization of tropical and subtropical fruits and vegetables. AVI publishing Company, Inc., Westport, Connecticut. pp.560.

Paull,R.E. 1992. Postharvest senescence and physiology of leafy vegetables. Postharvest News Inform. 3(1):11N$20 \mathrm{~N}$.

Rajesh, S.M. 2001. New trends in Fresh packaging. Indian Food Industry. 20(6): 49-52.

Ranganna, S. 1979. Handbook of analysis and quality control for fruits and vegetables, Tata McGraw- Hill Publishing Company Limited. New Delhi: 16-18.

Roura, S.I., L.A. Davidovich and C.E. Valle. 2000. Quality loss in minimally processed Swiss chard related to amount of damaged area. Lebensmittel Wissenschaft and Technologie. 3: 53-59.

Sandhya. 2010. Modified atmosphere packaging of fresh produce: Current status and future needs. Food Science and Technology 43: 381-392

Smyth, A. B., J. Song and A.C. Cameron. 1998. Modified atmosphere packaged cut iceberg lettuce: effect of temperature and $\mathrm{O}_{2}$ partial pressure on respiration and quality. Journal of Agricultural and Food Chemistry. 46: $4556-4562$.

Watada, A. E., N.P. Ko and D.A. Minott. 1996. Factors affecting quality of freshcut horticultural products. Postharvest Biology and Technology. 9: $115-125$.

Wills, R.B.H., W.B. Glasson, D. Grahm, T.H. Lee and E.G. Hall. 1989. Postharvest. AVI Van Nostrand Reinhold publishers, New York.

Yamauuchi, $\mathrm{N}$ and A.E.watada. 1991. Regulated chlorophyll degradation in spinach leaves during storage. J. Amer. Soc. Hort. Sci. 116:58-62.

Zagory, D. and A. Kader. 1988. Modified atmosphere packaging of fresh produce. Food technology. 42: 70-77.

Zhang, M., G.Xiao, J.Peng and V.M.Salokhe. 2003. Effects of modified atmosphere package on preservation of strawberries. Inst. Agrophysics. 17: 143-148.

\section{How to cite this article:}

Pragalyaashree, M.M., V. Thirupathi and John Kennedy, Z. 2017. Impact of Gas Composition, Temperature and Pre - Treatments on Mint Leaves Quality under Modified Atmosphere Packaging. Int.J.Curr.Microbiol.App.Sci. 6(6): 2616-2632. doi: https://doi.org/10.20546/ijcmas.2017.606.313 